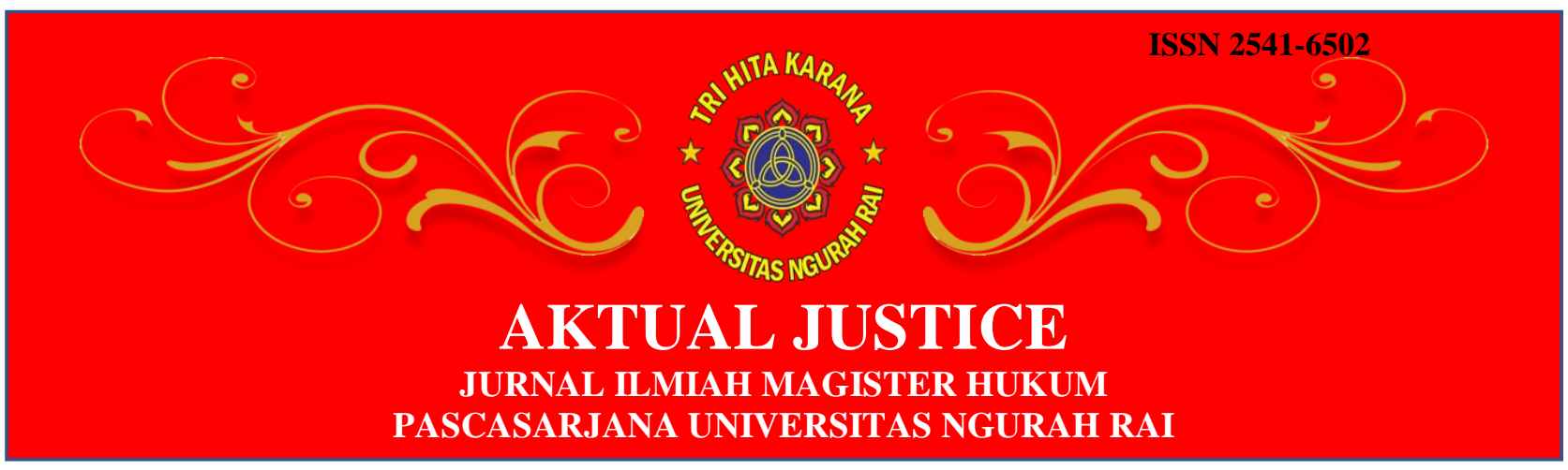

\title{
PERAN SERTA ORGANISASI PEMBERDAYAAN KESEJAHTERAAN KELUARGA (PKK) DALAM UPAYA PENCEGAHAN DAN PENANGANAN DINI KORBAN KEKERASAN
}

\author{
Anak Agung Istri Ari Atu Dewi, ${ }^{1}$ Anak Agung Ketut Sukranatha, ${ }^{2}$ \\ I Gusti Ayu Putri Kartika, ${ }^{3}$ Gusti Ayu Kade Komalasari ${ }^{4}$
}

\author{
${ }^{1}$ Dosen Fakultas Hukum Universitas Udayana, E-mail: ari_atudewi@unud.ac.id \\ 2Dosen Fakultas Hukum Universitas Udayana, E-mail: agung_sukranatha@unud.ac.id \\ 3Dosen Fakultas Hukum Universitas Udayana, E-mail: \\ ${ }^{4}$ Dosen Fakultas Hukum Universitas Mahendradata, E-mail: komalasari_51@yahoo.co.id
}

\begin{abstract}
The specific purpose and target of this research is to determine the role of family welfare empowerment organizations (PKK) in the prevention and early handling of women and children victims of violence. The reason for researching this topic is the increase in the number of victims of violence against women and children every year. Based on data from the Ministry of Women's Empowerment and Child Protection, it is shown that since 2012 it has increased from 18,718 to 54,041 cases in June 2017 and until February 2018 it has shown 374 cases of violence against women and children. In this case, the Government is responsible for providing optimal services needed by victims, both medical, psychological, and legal assistance in an effort to recover their condition. The government in providing services to victims should cooperate and partner with the community, especially in the prevention and early handling of victims of violence. Prevention and early handling of victims of violence at the village level can empower family welfare empowerment organizations (PKK) which are government partners that are considered effective in the prevention and early handling of women and children victims of violence in their areas. Based on these reasons, it is necessary to study in depth the role of the PKK organization in preventing and early handling of women and children victims of violence. To achieve specific goals and targets in this study, the research method used is a normative research method with a statue approach and a conceptual approach.

The results of the study provide an overview 1) there is a clear regulation in the laws and regulations related to the participation of the PKK in preventing and early handling of victims of violence, what needs to be further regulated is regulation in the form of Village Regulations and customary law (awig-awig) related to the participation of PKK and indigenous women in the prevention and early handling of victims of violence. 2) the procedures for preventing and early handling of victims of violence need to be stated in the operational standards in the village and the traditional village paparem.

Keywords: regulation, participation, victims of violence
\end{abstract}




\begin{abstract}
Abstrak
Tujuan dan target khusus dilakukan penelitian ini adalah untuk mengetahui pengaturan peran serta organisasi pemberdayaan kesejahteraan keluarga (PKK) dalam pencegahan dan penanganan dini perempuan dan anak korban kekerasan. Alasan diteliti topik ini dikarenakan peningkatan jumlah korban kekerasan perempuan dan anak setiap tahunnya. Berdasarkan data Kementerian Pemberdayaan Perempuan dan Perlindungan Anak ditunjukan sejak tahun2012 meningkat dari 18.718 menjadi 54.041 kasus pada Juni 2017 dan sampai februari 2018 menunjukan 374 kasus kekerasan perempuan dan anak. Dalam hal ini Pemerintah bertanggung jawab dalam memberikan layanan optimal yang dibutuhkan korban, baik medis, psikologis, dan bantuan hukum dalam upaya pemulihan kondisinya. Pemerintah dalam memberi layanan kepada korban seharusnya bekerjasama dan bermitra dengan masyarakat terutama dalam pencegahan dan penanganan dini korban kekerasan. Pencegahan dan penanganan dini korban kekerasan di tingkat desa dapat memberdayakan organisasi pemberdayaan kesejahteraan keluarga (PKK) yang merupakan mitra pemerintah yang dianggap efektif dalam pencegahan dan penanganan dini perempuan dan anak korban kekerasan di wilayahnya. Berdasarkan alasan tersebut, perlu dikaji secara mendalam terkait dengan pengaturan peran serta organisasi PKK dalam upaya mencegah dan penanganan dini perempuan dan anak korban kekerasan. Untuk mencapai tujuan dan target khusus dalam penelitian ini, metode penelitian yang digunakan adalah metode penelitian normatif dengan pendekatan peraturan perundang-undangan (statue approach) dan pendekatan konsep.

Hasil penelitian memberikan gambaran 1) ada pengaturan yang jelas dalam peraturan perundang-undangan terkait dengan peran serta PKK dalam melakukan pencegahan dan penanganan dini korban kekerasan, yang perlu diatur lebih lanjut adalah pengaturan dalam bentuk Peraturan Desa dan Hukum adat (awig-awig) terkait dengan peran serta PKK dan Perempuan masyarakat adat dalam pencegahan dan penanganan dini korban kekerasan. 2) tata cara dalam melakukan pencegahan dan penangan dini korban tindak kekerasan perlu dituangankan dalam Standar oprasional di desa dan paparem Desa adat.
\end{abstract}

Kata Kunci : pengaturan, peran serta, korban kekerasan

\title{
1. Pendahuluan
}

Anak adalah amanah Tuhan, dan mempunyai hak asasi yang harus dipenuhi, dihargai dan dilindungi. Anak juga merupakan tunas, potensi dan generasi penerus cita-cita bangsa yang memiliki peran strategis. Agar anak menjadi manusia yang cakap bagi dirinya sebagai manusia dan sebagai pewaris bangsa yang memikul tanggung jawab besar, maka anak perlu mendapatkan kesempatan yang seluas-luasnya 
untuk tumbuh dan berkembang secara optimal, baik fisik, mental, maupun sosial. Perlu dilakukan pula perlindungan untuk mewujudkan kesejahteraan anak dengan memberikan jaminan terhadap pemenuhan hak-haknya, dan perlakuan tanpa tindak kekerasan.

Undang-Undang Dasar Negara Republik Indonesia 1945 Pasal 28B ayat (2) menyatakan bahwa "Setiap anak berhak atas kelangsungan hidup, tumbuh dan berkembang serta berhak atas perlindungan dari tindak kekerasan dan diskriminasi“. Selanjutnya Pasal 72 Undang-Undang Nomor 23 Tahun 2002 tentang Perlindungan Anak mengamanatkan orang perorangan, masyarakat, lembaga swadaya masyarakat, dan lembaga pendidikan untuk berperan dalam perlindungan anak, termasuk di dalamnya melakukan upaya pencegahan tindak kekerasan terhadap anak di lingkungannya. Lebih lanjut dalam Pasal 1 angka 1 Undang-Undang Nomor 23 tahun 2002 tentang Perlindungan Anak menyebutkan bahwa yang dimaksud dengan anak adalah seseorang yang belum berusia 18 (delapan belas) tahun, termasuk anak yang masih dalam kandungan. Hal ini menunjukan bahwa oleh UU No. 23 Tahun 2002 bahwa janin yang masih dalam kandungan pun sudah mendapat perlindungan hukum.

Dengan demikian, menjadi tanggung jawab semua pihak untuk menegakkan aturan hukum yang berkaitan dengan perlindungan anak dalam aktivitas keseharian. Tindak kekerasan dalam bentuk apa pun terhadap anak tidak boleh terjadi karena dapat menimbulkan dampak negatif yang serius bagi tumbuh kembang anak. Tindak kekerasan merupakan pelanggaran berat hak azasi manusia serta merendahkan harkat dan martabat anak. Akibat tindak kekerasan anak mengalami penderitaan fisik, psikis dan sosial, sehingga mengganggu tumbuh kembangnya. Gambaran akibat tindak kekerasan dapat berupa luka, kecacatan, gangguan kejiwaan berupa rasa dendam, ketakutan dan 
depresi, penderitaan berkepanjangan akibat tindak kekerasan seksual, bahkan dapat menimbulkan kematian.

Berdasarkan Data Kementerian Pemberdayaan Perempuan dan Perlindungan Anak (Kemen PPPA) menyebutkan jumlah kekerasan yang terjadi terhadap perempuan dan anak selama kurun waktu lima tahun terakhir sejak 2012 meningkat dari 18.718 menjadi 54.041 kasus pada Juni 2017. Selanjutnya data kekerasan perempuan dan anak sampai februari 2018 menunjukan 374 kasus kekerasan. ${ }^{1}$ Kondisi angka tersebut menunjukkan perempuan dan anak menjadi kelompok paling rentan dari kekerasan, diskriminasi, dan eksploitasi. Dalam hal ini Pemerintah bertanggung jawab dalam memberikan layanan yang dibutuhkan korban, baik medis, psikologis, dan bantuan hukum dalam upaya pemulihan kondisinya. Wujud layanan pemerintah adalah adanya Pengaturan mengenai korban kekerasan diatur dalam UU 23 tahun 2004 tentang Penghapusan Kekerasan Dalam Rumah Tangga dan UU 23 Tahun 2002 tentang Perlindungan Anak sebagaimana telah diubah beberapa kali dan terkahir dengan UU 17 Tahun 2016 tentang Penetapan Peraturan Pengganti Undang-Undang Nomor 1 Tahun 2016 tentang Perubahan Kedua Atas Undang-Undang Nomor 23 Tahun 2002 Tentang Perlindungan Anak Menjadi Undang-Undang. Ditetapkannya UU tersebut seharusnya korban kekerasan perempuan dan anak dapat diminimalisir, namun berdasarkan data di atas menunjukan bahwa korban kekerasan perempuan dan anak semakin meningkat setiap tahunnya. Dalam konteks ini, solusi dan strategi yang tepat adalah pemberdayaan masyarakat melalui organisasi PKK di tingkat desa untuk ikut serta dalam upaya pencegahan dan penanganan korban kekerasan. Dengan demikian penting dilakukan kajian yang lebih

${ }^{1}$ http:// kekerasan.kemenpppa.go.id/, diakses 12 februari 2018. 
mendalam terkait dengan pengaturan peran serta PKK dan tata cara pencegahan dan penanganan dini korban kekerasan.

Berdasarkan fakta sosiologis tindak kekerasan terhadap anak terus meningkat dengan motif dan cara yang semakin beragam. Hampir tidak ada tempat yang aman bagi anak. Di rumah sendiri, di sekolah maupun di tempat umum tindak kekerasan dapat terjadi. Pelaku tindak kekerasan umumnya orang yang dekat dengan anak yakni orang tuanya, keluarga, guru atau orang dewasa lainnya, yang seharusnya bertanggung jawab untuk memberikan perlindungan terhadap anak. Tindak kekerasan terhadap anak dapat pula dilakukan oleh orang yang tidak dikenal di tempat umum. Perlindungan anak dari tindak kekerasan merupakan tanggung jawab utama orang tua, masyarakat sekitar, pemerintah daerah dan pemerintah. Berdasarkan data yang di dapat di POLDA Bali bahwa data kasus kekerasan anak sebagai korban dapat dilihat dalam tabel :

\begin{tabular}{|c|c|c|c|c|c|}
\hline \multirow{2}{*}{ No } & \multicolumn{5}{|c|}{ Tahun } \\
\cline { 2 - 6 } & 2010 & 2011 & 2012 & 2013 & 2014 \\
& (jan- & (jan- & (jan- & (jan- & (jan-feb) \\
& des) & des) & des) & des) & \\
\hline Jumlah & 144 & - & 146 & 148 & 21 \\
\hline
\end{tabular}

Sumber: diperoleh dari Kepolisian Negara Republik Indonesia Daerah Bali Direktorat Reserse Kriminal Umum Tahun 2010-2014

Terkait dengan data kasus kekerasan anak sebagai pelaku juga ddapat dilihat dalam tabel beriku :

\begin{tabular}{|l|c|c|c|c|c|}
\hline \multirow{2}{*}{ No } & \multicolumn{5}{|c|}{ Tahun } \\
\cline { 2 - 6 } & 2010 & 2011 & 2012 & 2013 & 2014 \\
\hline
\end{tabular}




\begin{tabular}{|l|c|c|c|c|c|}
\hline & $\begin{array}{c}\text { (jan- } \\
\text { des) }\end{array}$ & $\begin{array}{c}\text { (jan- } \\
\text { des) }\end{array}$ & $\begin{array}{c}\text { (jan- } \\
\text { des) }\end{array}$ & $\begin{array}{c}\text { (jan- } \\
\text { des) }\end{array}$ & (jan-feb) \\
\hline Jumlah & 120 & 76 & 79 & - & - \\
\hline
\end{tabular}

Sumber: diperoleh dari Kepolisian Negara Republik Indonesia Daerah Bali Direktorat

Reserse Kriminal Umum Tahun 2010-2014

Berdasarkan data-data tersebut jelas bahwa kekerasan terhadap anak merupakan ancaman bagi perkembangan anak itu sendiri yang merupakan penerus bangsa. Lebih lanju, banyak pula potret-potret kehidupan anak yang memang tidak sesuai dengan keberadaan UU No. 23 tahun 2002 tentang Perlindungan Anak yang seringkali anak-anak mendapat perlakuan yang tidak menyenangkan, baik dalam kehidupan rumah tangga, sekolah, bahkan dalam kehidupan masyarakat. Perlakuan yang tidak meyenangkan tersebut dapat diartikan bahwa anak tersebut mendapatkan kekerasan baik fisik maupun psikis, penelantaran. Sebagaimana dinyatakan oleh Mansour Fakih bahwa kekerasan (violence) adalah serangan atau invasi terhadap fisik maupun integritas mental psikologis seseorang ${ }^{2}$.Ada berbagai macam bentuk kekerasan (violence) terhadap anak yaitu kekerasan fisik, kekerasan Psikis, kekerasan ekonomi/penelantaran, kekerasan seksual ${ }^{3}$.

Tindak kekerasan terhadap anak merupakan kondisi yang sudah ada sejak lama di tengah-tengah masyarakat, tidak mengenal wilayah, suku, agama atau tingkat ekonomi, dan hampir ada pada semua lapisan masyarakat. Tindak kekerasan terhadap anak saat ini umumnya masih

2 Fakih, M. (1997). Analisis Gender dan Transformasi Sosial. Pustaka Pelajar Offset. h.17.

${ }^{3}$ Mufidah C.H. dkk. (2006). Haruskah Perempuan dan Anak Dikorbankan, Panduan Pemula untuk Pendampingan Korban Kekerasan Terhadap Perempuan dan Anak. Malang: Pilar Media. h. 7. 
dianggap urusan domestik keluarga atau urusan rumah tangga yang bersangkutan sehingga orang luar tidak boleh atau tidak mau ikut campur. Berdasarkan alasan tersebut, urgensi penelitian ini ditempatkan pada legalitas PKK dalam melakukan tindakan pencegahan dan penanganan dini korban kekerasan terutama pada korban perempuan dan anak di wilayahnya.

Hasil Pennelitian ini akan berpotensi terhadap berkurangnya korban kekerasan perempuan dan anak yang dapat dilakukan dengan penguatan organisasi-organisasi yang ada di tingkat desa seperti PKK. Penguatan organisasi tersebut dapat dilakukan dengan pengaturan yang jelas mengenai organisasi, tatacara serta prosedur yang tepat berkaitan dengan pencegahan dan penangan dini korban kekerasan, sehingga organsasi yang ada di tingkat desa dapat bergerak dan bertindaksesuai dengan dasar hukum yang jelas.

\section{Metode Penelitian}

a. Jenis Penelitian

Penelitian merupakan suatu sarana atau upaya pencarian untuk mengembangkan ilmu pengetahuan dan teknologi dengan cara menemukan, dan mengemukakan suatu kebenaran dengan melakukan suatu analisa. Menurut Peter mahmud Marzuki, "penelitian hukum adalah suau proses untuk menemukan aturan hukum, prinsip-prinsip hukum, maupun doktrin-doktrin hukum guna menjawab isu hukum yang dihadapi. ${ }^{4}$ Menurut Morris L. Cohen dan Kent C. Olson mengemukakan bahwa "Legal research is an essential component of legal practice. It is the process of finding the law that governs an activity and materials that explain or analyze

${ }^{4}$ Marzuki, P.M. (2005). Peneitian Hukum. Cetakan ke-1. Jakarta : Kencana. h. 35. 
that law".5 Selanjutnya Soerjono Soekanto mengemukakan bahwa, dalam ilmu hukum teradapat dua jenis penelitian hukum terdapat, yaitu penelitian hukum normatif dan penelitian hukum sosiologis atau empiris. ${ }^{6}$ Metode penelitian hukum Normatif yang disebut juga sebagai penelitian hukum doktrinal dan juga disebut penelitian hukum perpustakaan. Disebut penelitian hukum doktrinal karena penelitian ini dilakukan atau ditujukan pada peraturan- peraturan yang tertulis atau bahan-bahan hukum lain, sedangkan disebut sebagai penelitian perpustakaan atau studi dokumen karena penelitian ini lebih banyak dilakukan perpustakaan atau studi dokumen karena penelitian ini lebih banyak dilakukan pada bahan hukum yang bersifat sekunder yang ada diperpustakaan. ${ }^{7}$ Dalam penelitian ini digunakan jenis penelitian normatif, penelitian ini digunakan untuk membedah permasalahan yang terkait dengan pengaturan peran serta organisasi pemberdayaan kesejahteraan keluarga (PKK) dalam upaya pencegahan dan penanganan dini perempuan dan anak korban kekerasan. b. Sifat Penelitian

Sifat penelitian ini adalah kualitatif. Sifat penelitian yang kualitatif adalah jenis penelitian yang temuan-temuannya tidak diperoleh melalui prosedur statistik atau bentuk hitungan lainnya). Pada dasarnya penelitian kuallitatif didapat dari data dan bahan-bahan hukum yang meliputi, bukubuku, peraturan hukum, jurnal, hasil penelitian yang nantinya diramu lalu disajikan dalam suatu paparan deskripsi analisis.

c. Sumber Bahan Hukum

Sumber bahan hukum yang digunakan dalam penelitian ini meliputi bahan hukum primer dan bahan hukum sekunder. Bahan hukum

${ }^{5}$ Cohen, M.L dan Olson, K.C. (2000). Legal Research In A Nutshell. Seventh Edition, ST. Paul, Minn: West Group, h. 1.

6 Soekanto, S. (1986). Pengantar Penelitian Hukum. Jakarta : Universitas Indonesia (UI) Press). h. 51.

7 Waluyo, B. (1991). Penelitian Hukum Dalam Praktek. Jakarta: Sinar Grafika, h. 31. 
primer yang digunakan dalam penelitian ini adalah Peraturan perundang-undangan yang berlaku dan terkait dengan masalah yang dikaji. Adapun bahan hukum primer adalah Undang-Undang Dasar Negara Republik Indonesia Tahun 1945, tataran UU, PP, Peraturan Menteri, Perda Provinsi, Perda Kabpaten/Kota dan Peraturan Desa.

d. Teknik pengumpulan bahan hukum

Teknik pengumpulan bahan hukum yang digunakan dalam penelitian ini adalah dengan cara mengumpulkan dan menginvetarisasi bahan hukum primer dan bahan hukum sekunder berkaitan dengan permasalahan yang diteliti yang selanjutnya dilakukan pencatatan dengan secara detail. Dalam melakukan pengumpulan bahan hukum ini juga dilakukan suatu telaah kepustakaan dengan mencatat dan memahami informasi yang diperoleh dari bahan hukum primer dan bahan hukum sekunder serta bahan hukum penunjang lainnya yang berkaitan dengan permasalahan yang dibahas.

e. Teknik analisis bahan hukum

Bahan hukum yang telah terkumpul baik yang berasal dari bahan hukum primer maupun bahan hukum sekunder diolah dan dianalisis secara kualitatif. Pada tahap pengolahan, bahan hukum yang telah terkumpul dikatagorikan dan dikualifikasikan berdasarkan permasalahan penelitian, selanjutnya disusun secara sistematis sesuai dengan kerangka yang telah disiapkan sebelumnya. Pada tahap analisis, bahan hukum yang telah dikatagorikan dan dikualifikasi dianalisis dengan mengkaitkan bahan hukum satu dengan bahan hukum yang lainnya. Selanjutnya diadakan interprestasi dari bahan hukum tersebut untuk dapat menghasilkan simpulan tentang permasalahan yang diajukan. Interpretasi yang 
digunakan adalah terkait dengan hermeneutika hukum. ${ }^{8}$ Hermeneutika hukum pada intinya adalah metode interpretasi atas teks hukum, yang menampilkan segi tersurat yakni bunyi teks hukum dan segi tersirat yang merupakan gagasan yang ada di belakang teks hukum itu. Oleh karena itu untuk mendapatkan pemahaman yang utuh tentang makna teks hukum itu perlu memahami gagasan yang melatari pembentukan teks hukum dan wawasan konteks kekinian saat teks hukum itu diterapkan atau ditafsirkan. Kebenaran dalam ilmu hukum merupakan kebenaran intersubjektivitas, oleh karena itu penting melakukan konfirmasi dan konfrontasi dengan teori, konsep, dan pemikiran para sarjana yang mempunyai otoritas di bidang keilmuannya berkenaan dengan tematik penelitian ini. ${ }^{9}$ Keseluruhan hasil analisis, selanjutnya disajikan secara deskriptif yaitu dengan memaparkan secara lengkap segala persoalan yang terkait dengan masalah yang diteliti disertai dengan memberikan ulasan-ulasan secara kritis.

\section{Hasil Dan Pembahasan}

a. Pengaturan Peran Serta Organisasi Pemberdayaan Kesejahteraan Keluarga Dalam Pencegahan Dan Penanganan Dini Terhadap Perempuan Dna Anak Korban Kekerasan

Berbicara peran serta berarti memahami partisipasi. Dalam kamus besar Bahasa Indonesia menyatakan partisipasi adalah peran serta atau keikut sertaan (mengawas,mengontrol dan mengawasi) ${ }^{10}$. Lebih lanjut

${ }^{8}$ Irianto, S. (2009). Memperkenalkan Studi Sosiolegal dan Implikasi Metodologisnya, makalah dalam Metode Penelitian Hukum Konstelasi dan Refleksi. Editor Sulistyowati Irianto \&Shidarta. Jakarta : Yayasan Obor Indonesia, h. 181

9 Atmaja,G.M.W. (2012). Politik Pluralisme Hukum dalam Pengakuan Kesatuan Masyarakat Hukum Adat dengan Peraturan Daerah. Disertasi Doktor. Program Doktor Ilmu Hukum Fakultas Hukum Universitas Brawijaya. Malang, h. 17-18

${ }^{10}$ Hamidi, J. (2008). Panduan Praktis Pembentukan Peraturan Daerah Partisipatif. Jakarta : Prestasi Pustaka Publisher. h. 48. 
dikatakan bahwa keterlibatan masyarakat dalam pencegahan dan penanganan dini tindak kekerasan terhadap anak mulai dari tahap perencanaan sampai evalusi suatu produk hukum yang di bentuk.

Kebijakan Pencegahan dan Penanganan kekerasan terhadap anak sudah diatur dalam berbagai produk hukum baik secara nasional maupun internasional, yang harus dilaksanakan secara konsisten sebagai wujud keseriusan pemerintah dan masyarakat dalam upaya untuk mengatasi tindak kekerasan terhadap anak. Kebijakan-kebijakan yang menyatakan keterlibatan dan peran serta masyarakat dan komunitas dalam upaya pencegahan dan penanganan tindak kekerasan.

Protocol to Prevent, Suppress and Punish Trafficking in Persons, Especially Women and Children, Supplementing the United NationsConvention Against Transnational Organize Crime, telah diratifikasi melalui UndangUndang Nomor 14 Tahun 2009 tentang Pengesahan Protocol to Prevent, Suppress and Punish Trafficking in Persons, Especially Women and Children, Supplementing The United Nations Convention Against Transnational Organized Crime (Protokol Untuk Mencegah, Menindak, dan Menghukum Perdagangan Orang, Terutama Perempuan dan AnakAnak, Melengkapi Konvensi Perserikatan Bangsa-Bangsa Menentang Tindak Pidana Transnasional yang Terorganisasi).

Ditingkat regional, pada bulan Desember 1997 telah disepakati Deklarasi ASEAN yang disebut Declaration on Transnational Organized Crime Deklarasi ini menegaskan komitmen negara-negara ASEAN untuk bekerjasama dalam mencegah dan menindak kejahatan Transnational Organized Crime. Salah satu kejahatan yang termasuk Transnational Organized Crime adalah Tindak pidanan perdagangan orang yang merupakan tindakan kekerasan. Kebijakan-kebijakan yang mengatur partisipasi masyarakat dalam pencegahan dan penanganan tindak kekerasan juga diatur dalanm tataran hukum nasional. Hal itu dapat dilihat 
dalam beberapa peraturan hukum Indonesia, yaitu : di dalam UndangUndang Nomor 39 Tahun 1999 tentang HAM, Pasal 29 ayat (1) menyebutkan bahwa "Setiap orang berhak atas perlindungan diri pribadi, keluarga, kehormatan, martabat dan hak miliknya". Selanjutnya Pasal 30 menyebutkan bahwa "Setiap orang berhak atas rasa aman dan tenteram serta perlindungan terhadap ancaman ketakutan untuk berbuat atau tidak berbuat sesuatu".

Mengenai partisipasi juga diatur dalam Undang-Undang Nomor 21 Tahun 2007 tentang Pemberantasan Tindak Pidana Perdagangan Orang, beberapa pasalnya mengamanatkan tentang peran dan partisipasi masyarakat dalam pencegahan dan penanganan TPPO yang merupakan bagian dari tindak kekerasan. Dalam UU 21 tahun 2007 di jelaskana dalam Pasal 60 yang pada prinsipnya memuat tentang peran serta masyarakat dalam upaya pencegahan dan penanganan TPPO. Demikian bpula bentuk bentuk dalam pencegahan dan penanganan tindak kekerasan tersebut dapat dilakukan diantaranya : pertama, Pemberian informasi dan/atau melaporkan tentang terjadinya TPPO kepada penegak hukum; dan kedua, Ikut menangani korban TPPO. Lebih lanjut dalam Pasal 61 juga menyatakan yang pada prinsipnya menyatakan bahwa Pemerintah wajib membuka akses seluas-luasnya bagi peran serta masyarakat baik nasional maupun internasional sesuai ketentuan peraturan perundang-undangan, hukum, dan kebiasaan internasional yang berlaku. Begitu pula dalam Pasal 62, yang pada prinsipnya mengatakan bahwa masyarakat yang terlibat dalam upaya pencegahan dan penanganan TPPO berhak memperoleh perlindungan hukum. Yang tidak kalah pentingnya adalah norma yang diatur dalam Pasal 63, yang pada prinsipnya menyatakan bahwa peran serta masyarakat tersebut dilaksanakan secara bertanggung jawab sesuai dengan ketentuan peraturan perundang-undangan. Penormaan dalam pasal-pasal tersebut menbuktikan bahwa peranserta atau partisipasi 
masyarakat sangat penting dan sudah diatur dalam produk hukum Indonesia dalam hal pencegahan dan penanganan tindak kekerasan.

Peraturan Pemerintah Nomor 9 Tahun 2008 tentang Tata Cara dan Mekanisme Pelayanan Terpadu Bagi Saksi dan/atau Korban Tindak Pidana Perdagangan Orang yaitu bahwa pemerintah di dalam memberikan penyelenggaraan dan perlindungan sosial serta pusat trauma bagi korban, sebagaimana diatur dalam Pasal 16 Ayat (1) ini, dapat mendayagunakan rumah perlindungan sosial atau pusat trauma milik masyarakat atau lembaga-lembaga pelayanan sosial lainnya.

Peraturan Presiden Republik Indonesia Nomor 69 Tahun 2008 tentang Gugus Tugas Pencegahan dan Penanganan Tindak Pidana Perdagangan Orang, dalam Pasal 7 menjelaskan bahwa salah satu anggota Gugus Tugas Pencegahan dan Penanganan Tindak Pidana Perdagangan Orang (GT-PPTPPO )adalah unsur-unsur dari organisasi masyarakat, lembaga swadayamasyarakat, organisasi profesi dan peneliti/akademisi, penegak hukum dan pemerintah. Gugus Tugas ini antara lainbertugas mengkoordinasikan segala upaya pencegahan dan penanganan TPPO.

Peraturan Menteri Koordinator Bidang Kesejahteraan Rakyat Republik Indonesia No.25/KEP/MENKO/KESRA/VIII/2009 tentang Rencana Aksi Nasional Pemberantasan Tindak Pidana Perdagangan Orang (RAN-PTPPO) dan Eksploitasi Seksual Anak (ESA) 2009-2014. Keterlibatan masyarakat dan komunitas dalam RAN-PTPPO tergambar pada Rencana Aksi Sub Gugus Tugas Bidang PencegahandanPartisipasi Anak, antara lain:

a) terbangunnya mekanisme nasional untuk pengawasan dan perlindungan dalam memberantas kejahatan TPPO dan ESA, yang melibatkan masyarakat melaluikampanye berbasis komunitas di daerah rawan melalui kelompok-kelompok basis (PKK, Karang Taruna, kelompok pengajian, kelompok sadar wisata, dll); 
b) Keterlibatan masyarakat dan komunitas dalam RAN-PTPPO tergambar pada Rencana Aksi SubGugus Tugas Bidang Penegakan Hukum, antara lain; dan (c) mengembangkan dan memperkuat kelompok Swadaya Masyarakat dalam pengawasan dan penanganan TPPO.

Partisipasi masyarakat dalam Pencegahan dan penanganan dini tindak kekerasan juga diatur dalam Peraturan Menteri Negara Pemberdayaan Perempuan Dan Perlindungan Anak Republik Indonesia Nomor 08 TAHUN 2012, yang secara eksplisist menyebutkan bahwa partisipasi masyarakat melalui kelompok PKK termasuk di dalamnya kelompok dasawisma dapat diberdayakan untuk pencegahan dan penanganan dini tindak kekerasan terhadap anak. Sesuai dengan Pasal 1 angka 1 yang menyatakan bahwa Kelompok Dasawisma adalah kelompok yang terdiri 10 (sepuluh) sampai 20 (dua puluh) rumah, diketuai oleh salah seorang ketua yang dipilih di antara mereka, sebagai kelompok potensial dalam pelaksanaan kegiatan Pemberdayaan dan Kesejahteraan Keluarga (PKK). Dalam Konsidran menimbang pada PERMEN Pemebrdayaan Perempuan dan Perlindungan Anak Nomor 08 TAHUN 2012 disebutkan bahwa kelompok dasawisma dalam organisasi PKK Desa merupakan kelompok potensial untuk melakukan upaya pencegahan dan penanganan dini tindak kekerasan terhadap anak, oleh karena itu kelompok PKK ini perlu dikuatkan dan ditingkatkan peranannya.

Selain itu dalam penguatan kelompok PKK Desa juga dapat dilakukan dengan penguatan aturan hukum adatnya, dimana hukum adat merupakan aturan hukum yang mengikat bagi masyarakat adat. Dengan demikian PKK yang ada di tingkat desa dapat mengembangkan strategi utuk melakukan perlindungan dan penanganan dini anak korban kekerasan melalui pemberdayaan perempuan-perempuan masyarakat adat sehingga dapat mengurangi tindakan-tindakan kekerasan terhadap anak 
maupun dapat meningkatan penanganan dini korban kekerasan terhadap anak.

Dengan demikian tampaknya melalui norma-norma hukum adat sebagaimana pada masyarakat adat di Bali, aturan hukum adat yang disebut dengan Awig-Awig menjadi penting untuk di kembangkan terutama dalam pengaturan pencegahan dan penanganan dini anak korban kekerasan.

Berdasarkan paparan di atas, jelas bahwa peran serta atau partisipasi PKK dalam pencegahan dan penanganan dini tindak kekerasan terhadap anak mendapat pengaturan yang jelas dalam paraturan perundang-udangan. Pengaturan yang eksplisit ini membuktikan bahwa peraserta kelompok dasawisma tersebut perlu penguatan lebih lanjut dan ditingkatkan peranannya di desa adat, yaitu penting untuk diatur dalam hukum adat atau pada mayarakat adat di Bai, penting untuk dituangkan dalam awig-awig desa adat mengenai penormaan peran perempuan krama desa adat dalam melakukan pencegahan dan penanganan dini tindak kekerasan terhadap anak.

\section{b. Tata Cara PKK Dalam Upaya Melakukan Pencegahan Dan Penanganan Dini Korban Kekerasan.}

Masyarakat dan komunitas yang sudah memiliki pemahaman yang baik dan mampu secara tegas dan terbuka memberikan dukungan pada korban, menjadi dasar yang kuat untuk melakukan pencegahan tindak kekerasan terhadap anak. Pengorganisasian kelompok ini bisa dibagi menjadi dua kelompok yaitu kelompok pertama adalah kelompok yang secara langsung akan memberikan informasi secara personal kepada individu, sedangkan kelompok kedua adalah kelompok yang terus menerus mengkampanyekan pemahaman tindak kekerasan, kesetaraan dan keadilan gender, anti diskriminasi dan anti perdagangan orang. 
Terkait dengan Pencegahan dalam Pasal 4 PERMEN Pemberdayaan Perempuan dan Perlindungan Anak Nomor 08 Tahun 2012 jelas di sebutkan bahwa Pemerintah, Pemerintah Daerah dan Tim Penggerak PKK Pusat, Provinsi, Kabupaten/Kota, Kecamatan, Desa/ Kelurahan melakukan:

a. sosialisasi, advokasi, penyuluhan pencegahan dan penanganan dini tindak kekerasan terhadap anak;

b. pelatihan tentang pencegahan dan penanganan dini tindak kekerasan terhadap anak;

c. peningkatan koordinasi, penguatan jejaring dan kemitraan dengan lintas sektor terkait;

d. fasilitasi penanganan dini tindak kekerasan terhadap anak; dan

e. pencatatan kasus tindak kekerasan terhadap anak.

Hal di atas menunjukan bahwa pemerintah daerah melalui kebijakan-kebijakan hukumnya mengatur pencegahan tindak kekerasan terhadap anak melalui kelompok-kelompok dasawisma yang ada di desa dengan harapan untuk meminimalisir tindak kekerasan terhadap anak. Mengingat kelompok dasawisma merupakan kelompok yang potensial terdepan dalam pelaksanaan kegiatan Pemberdayaan dan Kesejahteraan Keluarga (PKK). Kelompok ini berfungsi sebagai unsur penggerak dan pembina warga masyarakat di lingkungannya untuk melaksanakan 10 program pokok PKK di tingkat keluarga, yang diataranya adalah pencegahan dan penanganan dini tindak kekerasan.

Upaya-upaya yang dapat dilakukan oleh kelompok daswisma dalam pencegahan dan penangan dini tindak kekerasan terhadap anak melalui dua (2) tahapan yaitu :

1. Pencegahan tindak kekerasan terhadap anak merupakan upaya yang harus dilakukan oleh semua pihak, baik negara, pemerintah, masyarakat, keluarga, maupun anak itu sendiri. Undang-Undang 
Nomor 23 Tahun 2004 tentang Penghapusan Kekerasan Dalam Rumah Tangga Pasal 15 yang menyatakan bahwa "Setiap orang yang mendengar, melihat, atau mengetahui terjadinya tindak kekerasan dalam rumah tangga wajib melakukan upaya-upaya sesuai dengan batas kemampuannya untuk: a. mencegah berlangsungnya tindak pidana; b. memberikan perlindungan kepada korban; c. memberikan pertolongan darurat; dan $\mathrm{d}$. membantu proses pengajuan permohonan penetapan perlindungan. Merujuk Pasal 15 diatas maka upaya pencegahan tindak kekerasan terhadap anak dapat dilakukan dengan cara sebagai berikut:

a) Di Lingkungan Keluarga, ada beberapa hal yang dapat dilakukan dalam lingkungan keluarga diantaranya :

- Peningkatan keimanan dan ketakwaan terhadap Tuhan Yang Maha Esa.

- Peningkatan pemahaman tentang hak asasi manusia, hakhak anak, dan kesetaraan gender.

- Peningkatan kesadaran hukum dan dampak tindak kekerasan terhadap anak.

- Pengintegrasian program pencegahan tindak kekerasan terhadap anak dalam program pemberdayaan keluarga.

- Penerapan pola pengasuhan anak yang bebas dari tindak kekerasan, dan penguatan pendidikan anti tindak kekerasan sejak dini di tingkat keluarga.

b) Di lingkungan Masyarakat

- Peningkatan pemahaman tentang hak asasi manusia, hakhak anak, dan kesetaraan gender.

- Peningkatan kesadaran masyarakat tentang hukum dan dampak tindak kekerasan terhadap anak. 
- Pengintegrasian program pencegahan tindak kekerasan terhadap anak dalam program pemberdayaan masyarakat.

- Penguatan peran komunitas peduli anak melalui pelatihan pola pengasuhan anak.

- Mendorong upaya penegakan ketentuan Peraturan Perundang-undangan Republik Indonesia untuk mencegah tindak kekerasan terhadap anak.

Pada tahap pelaksanaannya, pencegahan tindak kekerasan terhadap anak dalam keluarga dapat dilakukan dengan mengintegrasikannya dalam pola pengasuhan yang bebas dari tindak kekerasan. Sedangkan peran serta masyarakat dalam pencegahan tindak kekerasan terhadap anak bisa dilakukan melalui pola penguatan komunitas peduli anak. Dalam konteks ini PKK desa berkewajiban dalam melakukan pencegahan tindakan kekerasan terhadap anak. Tata cara dalam melakukan pencegahan telah jelas diatur dalam peraturan perundang-undangan. Berkaitan dengan peran serta perempuan masyarakat hukum adat dalam melakukan pencegahan tindakan kekerasan terhadap anak, perlu dilakukan pengaturan dalam hukum adatnya, sehingga perempuan masyarakat adat mampu melakukan tindakan dini dalam melakukan pencegaan tindak kekerasan terhadap anak. Dalam masyarakat adat di Bali, pengaturan peran serta perempuan desa adat sebagai krama desa adat dalam melakukan pencegahan kekerasan terhadap anak perlu diatur dalam pararem desa adat.

2. Penanganan tindak kekekerasan terhadap anak.

Konsep yang dibangun mengenai penanganan dini tindak kekerasan adalah tindakan awal atau segera setelah terjadinya tindak kekerasan terhadap anak. Penanganan tindak kekerasan terhadap anak yang dimakasud tersebut telah ditetapkan dalam Peraturan Menteri 
Negara Pemberdayaan Perempuan Nomor 01 Tahun 2010 tentang Standar Pelayanan Minimal Bidang Layanan Terpadu Bagi Perempuan dan Anak Korban Tindak Kekerasan yang meliputi lima jenis layanan sebagai berikut:

\section{Layanan Pengaduan}

Layanan pengaduan/identifikasi korban adalah layanan pertama yang diberikan kepada dan didapat oleh korban pada waktu memasuki lembaga layanan. Layanan pengaduan berbentuk proses identifikasi kondisi korban, asesmen, persiapan penanganan untuk korban, dan rencana intervensi atau tindakan yang diperlukan oleh korban.

2. Layanan kesehatan

Layanan kesehatan adalah pemulihan korban dari gangguan kesehatan yang dideritanya, baik fisik maupun psikis. Jenis layanan berupa :

a. pelayanan non kritis;

b. pelayanan semi kritis;

c. pelayanan kritis; dan

d. pelayanan medikolegal.

Pemberian layanan ini dilakukan oleh dokter, dokter gigi, perawat atau bidan yang telah dilatih tentang tata laksana kasus tindak kekerasan terhadap perempuan dan anak. Pelayanan spesialistik dilakukan oleh tenaga medis spesialistik, ada pun tata laksana pelayanan medis mengacu pada Panduan Pengembangan Puskesmas Mampu KTP/A dan Prosedur Standar Operasional (SOP) rumah sakit.

3. Layanan rehabilitasi sosial

Rehabilitasi sosial adalah layanan yang ditujukan untuk memulihkan dan mengembangkan kemampuan seseorang yang mengalami disfungsi sosial, agar dapat melaksanakan fungsi sosialnya kembali secara wajar. Dalam Rehabilitasi Sosial korban mendapat layanan :

a. kontrak sosial; 
b. konseling awal;

c. konseling lanjutan;

d. bimbingan mental dan spiritual;

e. pendampingan; dan

f. rujukan.

Layanan tersebut dilakukan oleh pekerja sosial, psikolog sosial, psikolog klinis, petugas konseling terlatih. Pada kasus tertentu dimana korban mengalami depresi berat, dilakukan penanganan oleh psikiater. Ada pun tata laksana pelayanan psikososial mengacu pada Prosedur Standar Operasional (SOP) masing-masing tempat pelayanan.

4. Layanan bantuan hukum

Bantuan hukum adalah layanan yang diberikan oleh pendamping, maupun aparat penegak hukum, yang meliputi pemberian konsultasi hukum, menjalankan kuasa, mewakili, mendampingi, membela dan melakukan tindakan hukum lain untuk korban tindak kekerasan. Layanan bantuan hukum diberikan dalam bentuk:

a. perlindungan saksi dan korban;

b. Berita Acara Pemeriksaan (BAP);

c. penuntutan;

d. putusan; dan

e. restitusi.

Layanan bantuan hukum termasuk di dalamnya konsultasi hukum, pendampingan, pembelaan yang dilakukan oleh petugas yang membidangi hukum, seperti polisi, kejaksaan, pengadilan negeri, lembaga advokat, lembaga perlindungan saksi dan korban, lembaga masyarakat, Pusat Pelayanan Terpadu Perlindungan Perempuan dan Anak (P2TP2A). Adapun tata laksana bantuan hukum mengacu pada Prosedur Standar Operasional (SOP) yang berlaku di tiap tersebut.

5. Layanan pemulangan dan reintegrasi sosial 
Layanan pemulangan adalah upaya mengembalikan korban tindak kekerasan dari luar negeri ke titik debarkasi atau dari daerah penerima/terjadinya tindak kekerasan ke daerah asal atau pihak keluarga, keluarga/institusi pengganti, atau masyarakat yang dapat memberikan perlindungan dan pemenuhan kebutuhan korban tindak kekerasan. Adapun reintegrasi sosial adalah upaya untuk menyatukan kembali korban tindak kekerasan kepada keluarganya, masyarakat, lembaga atau lingkungan sosial lain yang dapat memberikan perlindungan. Layanan pemulangan dan reintegrasi sosial dilakukan berkoordinasi dengan dinas terkait untuk menyiapkan pemulangan korban dan reintegrasi sosial tersebut. Adapun jenis layanan yang diberikan adalah :

a. penyatuan dengan keluarga/keluarga pengganti;

b. pemberdayaan ekonomi dan sosial;

c. pendidikan; dan

d. monitoring dan bimbingan lanjut.

Pemulangan dan reintegrasi sosial dilakukan oleh Kementerian Luar Negeri, Dinas Sosial, Dinas Tenaga Kerja, Dinas Pendidikan, Dinas Perhubungan, Badan Nasional Penempatan dan Perlindungan Tenaga Kerja Indonesia (BNP2TKI), Balai Pelayanan Penempatan dan Perlindungan Tenaga Kerja Indonesia (BP3TKI), Kesatuan Pelaksana Pengamanan Pelabuhan (KP3), Unit Pemberdayaan Perempuan dan Perlindungan Anak di daerah, lembaga masyarakat. Tata laksana kegiatan pemulangan dan reintegrasi sosial mengacu pada Prosedur Standar Operasional (SOP) masing-masing. Dalam kasus korban berada dalam bahaya yang berasal dari luar, misalnya korban perdagangan orang, maka korban ditempatkan dalam rumah aman/rumah perlindungan untuk melindungi korban dari pelaku perdagangan orang. Kegiatan ini dilakukan oleh pemerintah dan pemerintah daerah (Dinas Sosial) dan lembaga 
masyarakat. Tata laksana pelayanan di rumah aman mengacu pada Prosedur Standar operasional (SOP) masing-masing. Dalam pelaksanaan penanganan anak korban tindak kekerasan peran serta masyarakat merupakan garda terdepan. Dalam hal ini Kelompok Dasawisma dapat juga melakukan penanganan dini dengan cara yang sangat sederhana misalnya memberikan pertolongan pertama atau melaporkan tindak kekerasan yang terjadi kepada Ketua RT atau kepada pihak lainnya, atau melakukan pelaporan kepada polisi melalui Unit Pelayanan Perempuan dan Anak (UPPA) dan maupun langsung kepada Pusat Pelayanan Terpadu jika tindak kekerasan mengancam jiwa anak atau sudah terjadi berulang kali. Pusat Pelayanan Terpadu merupakan unit kerja fungsional yang menyelenggarakan pelayanan terpadu untuk korban.

Berkaitan dengan tatacara PKK dalam melakukan penganan dini korban kekerasan telah diatur secara jelas dalam beberapa peraturan perundang-undangan. Untuk lebih efektif PKK dalam melakukan penanganan dini korban tindak kekerasan, perlu ditaur dalam Peraturan Desa atau Perdes dan awig-awig desa adat maupun paparem desa adat.

\section{Kesimpulan}

1. Pengaturan peran serta organisasi Pemberdayaan Kesejahteraan Keluarga dalam pencegahan dan penanganan dini terhadap perempuan dan anak korban kekerasan dapat dilihat dalam peraturan perundangundangan yaitu Undang-Undang Nomor 39 Tahun 1999 tentang HAM, Undang-Undang Nomor 21 Tahun 2007 tentang Pemberantasan Tindak Pidana Perdagangan Orang, Peraturan Pemerintah Nomor 9 Tahun 2008 tentang Tata Cara dan Mekanisme Pelayanan Terpadu Bagi Saksi dan/atau Korban Tindak Pidana Perdagangan Orang, Peraturan Presiden Republik Indonesia Nomor 69 Tahun 2008 tentang Gugus Tugas Pencegahan dan Penanganan Tindak Pidana Perdagangan Orang, Peraturan Menteri Negara Pemberdayaan Perempuan Dan 
Perlindungan Anak Republik Indonesia Nomor 08 Tahun 2012. Dalam hal ini jelas diatur peran serta PKK dalam melakukan tindakan pencegahan dan penanganan dini korban kekerasan, yang perlu dikembangkan adalah pengaturan dalam bentuk Peraturan Desa (Perdes) dan pengaturan dalam hukum adat (awig-awig di Bali). Dengan pengaturan yang komprehensif dalam berbagai peraturan hukum berdampak pada arah dan kepastian yang jelas bagi PKK dalam melakukan tindakan pencegahan dan penanganan dini korban kekerasan.

2. Tata cara PKK dalam upaya melakukan pencegahan dan penanganan dini korban kekerasan di wilayahnya adalah dapat dilihat dalam peraturan perundang-undangan yaitu dalam upaya pencegahan dapat dilakukan dengan sosialisasi dan pelatihan dalam melakukan tindakan pencegahan dan penanganan dini korban kekerasan. Dalam tindak penanganan dini, PKK dapat melakukan atau menyediakan layananan Pengaduan, Layanan Kesehatan, Layanan rehabilitasi sosial, layanan bantuan hukum dan layanan pemulangan dan reintegrasi sosial. Tata cara ini perlu dituangkan dalam Peraturan Desa dan Pararem Desa Adat.

\section{DAFTAR PUSTAKA}

\section{Buku}

Cohen, M.L dan Olson, K.C. (2000). Legal Research In A Nutshell. Seventh Edition, ST. Paul, Minn: West Group

Fakih, M. (1997). Analisis Gender dan Transformasi Sosial. Pustaka Pelajar Offset.

Hamidi, J. (2008). Panduan Praktis Pembentukan Peraturan Daerah Partisipatif. Jakarta : Prestasi Pustaka Publisher 
Irianto, S. (2009). Memperkenalkan Studi Sosiolegal dan Implikasi Metodologisnya, makalah dalam Metode Penelitian Hukum Konstelasi dan Refleksi. Editor Sulistyowati Irianto \&Shidarta. Jakarta : Yayasan Obor Indonesia

Marzuki, P.M. (2005). Peneitian Hukum. Cetakan ke-1. Jakarta : Kencana.

Mufidah C.H. dkk. (2006). Haruskah Perempuan dan Anak Dikorbankan, Panduan Pemula untuk Pendampingan Korban Kekerasan Terhadap Perempuan dan Anak. Malang : Pilar Media

Soekanto, S. (1986). Pengantar Penelitian Hukum. Jakarta : Universitas Indonesia (UI) Press

Waluyo, B. (1991). Penelitian Hukum Dalam Praktek. Jakarta: Sinar Grafika

\section{Disertasi}

Atmaja,G.M.W. (2012). Politik Pluralisme Hukum dalam Pengakuan Kesatuan Masyarakat Hukum Adat dengan Peraturan Daerah. Disertasi Doktor. Program Doktor Ilmu Hukum Fakultas Hukum Universitas Brawijaya. Malang

\section{Artikel Internet}

http:/ / kekerasan.kemenpppa.go.id/, diakses 12 februari 2018. 